\title{
Evaluation of the efficiency of an integrated biofilm and phytoremediation system with Nasturtium officinale for the treatment of municipal wastewater in Huancavelica
}

\section{Evaluación de la eficiencia de un sistema integrado de biofilm y fitorremediación con Nasturtium officinale para el tratamiento de aguas residuales municipales en Huancavelica}

\author{
Adiel Álvarez Ticllasuca ${ }^{1}$, Marco Curasma Matamoros ${ }^{2}$, Estefani Karen Sandoval Condori ${ }^{2}$ and \\ Fernando Toribio Román ${ }^{2}$ \\ 'Universidad Nacional Autónoma de Tayacaja Daniel Hernández Morillo, Perú. \\ ${ }^{2}$ Universidad Nacional de Huancavelica, Perú.
}

\begin{abstract}
In this research removal efficiency was evaluated of organic pollutants of a biofilm and phytoremediation integrated system for municipal wastewater treatment in Huancavelica. A pilot plant consisting of a settler was installed that also retained oils and fats, a biological filter using as support material the calcareous stuff and a phytoremediation process with Nasturtium officinale (watercress) The hydraulic retention time was 5.5 hours and the flowrate of $0.011 \mathrm{~L} \mathrm{~s}-1$, the evaluation was made of the proper functioning of processes by monitoring control parameters. The pollutant removal efficiency was determined by Student's "t" test $(\mathrm{p}<0.05)$. An average $\mathrm{pH}$ value of 7.57 and a temperature of $12.07^{\circ} \mathrm{C}$ were obtained, subsequently the measurement of BOD5 was initiated, obtaining maximum effluent values of $131 \mathrm{ppm}$ and minimum values of $45 \mathrm{ppm}$ and a removal efficiency of $44.8 \%$ was obtained, for COD. In total coliforms, fecal coliforms and Escherichia coli the removal was $66.67 \%, 94.59 \%, 81.22 \%$ and $72.12 \%$ respectively, oil and fat analysis was also performed and total suspended solids, however high removal efficiency was not obtained. It is concluded that the parameters of BOD5 and COD comply with the MPL for the effluents of municipal domestic wastewater treatment plants, while the rest of the parameters analyzed do not comply with the regulations. however high removal efficiency was not obtained. It is concluded that the parameters of BOD5 and COD comply with the MPL for the effluents of municipal domestic wastewater treatment plants, while the rest of the parameters analyzed do not comply with the regulations. however high removal efficiency was not obtained. It is concluded that the parameters of BOD5 and COD comply with the MPL for the effluents of municipal domestic wastewater treatment plants, while the rest of the parameters analyzed do not comply with the regulations.
\end{abstract}

Keywords: wastewater, integrated system, biofilm, phytoremediation.

Adiel Álvarez Ticllasuca. ORCID: https://orcid.org/0000-0002-5410-0571 email: adielalvarez@unat.edu.pe

Marco Curasma Matamoros. ORCID: https://orcid.org/00-0002-5659-9273 email: marcoanotoniocurasmamatamoros@gmail.com

Estefani Sandoval Condori. ORCID: https://orcid.org/00-0001-5391-1543 email: estefanikaren71@gmail.com

Fernando Toribio Román. ORCID: https://orcid.org/0000-0003-1139-9232 email: toribioroman@gmail.com 


\section{RESUMEN}

En esta investigación se evaluó la eficiencia de remoción de contaminantes orgánicos de un sistema integrado de biofilm y fitorremediación para el tratamiento de aguas residuales municipales en Huancavelica. Se instaló una planta piloto conformada por un poblador que también retuvo aceites y grasas, un filtro biológico utilizando como material de soporte el material calcáreo y un proceso de fitorremediación con Nasturtium officinale (berro) El tiempo de retención hidráulica fue de 5.5 horas y el caudal de $0.011 \mathrm{~L} \mathrm{~s}-1$, se realizó la evaluación del correcto funcionamiento de los procesos mediante el monitoreo de parámetros de control. La eficiencia de eliminación de contaminantes se determinó mediante la prueba " $t$ " de Student $(\mathrm{p}<0,05)$. Se obtuvo un valor medio de $\mathrm{pH}$ de 7,57 y una temperatura de $12,07^{\circ} \mathrm{C}$, posteriormente se inició la medición de $\mathrm{DBO}$, obteniendo valores máximos de efluentes de $131 \mathrm{ppm}$ y valores mínimos de $45 \mathrm{ppm}$ y se obtuvo una efíciencia de eliminación del 44,8\%, para DQO. En coliformes totales, coliformes fecales y Escherichia coli la eliminación fue de $66.67 \%, 94.59 \%$, $81.22 \%$ y $72.12 \%$ respectivamente, también se realizó análisis de aceite y grasa y se obtuvieron sólidos suspendidos totales, sin embargo no se obtuvo una alta eficiencia de eliminación. Se concluye que los parámetros de DBO5 y DQO cumplen con el MPL para los efluentes de las plantas de tratamiento de aguas residuales domésticas municipales, mientras que el resto de los parámetros analizados no cumplen con la normativa. sin embargo, no se obtuvo una alta eficiencia de eliminación. Se concluye que los parámetros de DBO5 y DQO cumplen con el MPL para los efluentes de las plantas de tratamiento de aguas residuales domésticas municipales, mientras que el resto de los parámetros analizados no cumplen con la normativa. sin embargo, no se obtuvo una alta eficiencia de eliminación. Se concluye que los parámetros de DBO5 y DQO cumplen con el MPL para los efluentes de las plantas de tratamiento de aguas residuales domésticas municipales, mientras que el resto de los parámetros analizados no cumplen con la normativa.

Palabras clave: aguas residuales, sistema integrado, biofilm, fitorremediación.

\section{INTRODUCTION}

$I_{8}^{8}$ gnorance of the principles of wastewater treatment has generated the collapse of a set of wastewater treatment plants within the Huancavelica region, due to inadequate operation and maintenance, generating a very high degree of contamination and contaminating aquatic systems, which that causes and affects public health (Rodrigues et al., 2016).

According to the problem within the Huancavelica region, a system has been studied whose purpose is to reduce the concentration of organic and microbiological pollutants which can be applied in the future, for this the efficiency of removal of organic pollutants from the system was analyzed.

There is a wide variety of technologies based on biofilm processes, each with its specific characteristics (Monzón et al., 2012). LPhytoremediation strategies refer to the predominant mechanisms performed by the plants themselves, but also, in some cases, indicate the role of microbial communities during the remediation process (Núñez, et al., 2004), the system used in This research combined a biological medium concentrated in a filter bed and a phytoremediation process with Nasturtium officcinale (watercress), these processes forming an integrated system, the same that worked continuously, an integrated system is not considered a type of system within the general theory of systems, but it can be immersed within an open system considering criteria such as; be composed of two and more elements that interact and differ with each other (Hammond, 2010),ron two elements of treatment or processes for better functionality as a system. For the design, data were taken from a wastewater characterization study, the same one that was carried out at the point of arrival at the desander; where the presence of organic pollutants was found, which were measured through the BOD5.

The objective of the research was to evaluate the efficiency Attribution-NonCommercial 4.0 International (CC BY-NC 4.0) of removal of organic pollutants from the concentration of BOD5 implemented with this treatment technology, also, to know its removal capacity, additional parameters such as COD, oils and fats, total solids were analyzed. in suspension, total coliforms, fecal coliforms and Escherichia coli, showing a very significant level of removal, this system worked with a hydraulic retention time of 5.5 hours.

The parameters ofl $\mathrm{pH}$ and water temperature were controlled more frequently as they define stability conditions, since a sudden change in $\mathrm{pH}$ can alter or hinder the biological system; likewise, low water temperatures limit its ability to degrade organic matter. During the study process, low temperatures were observed, as well as sudden changes in temperature behaved as an indicator, allowing the system to adapt to these phenomena and evaluate the removal and treatment capacity, or in more common terms, the ability to reduce pollutants that can degrade water resources, in this case being the Ichu River. The research proposes an alternative for municipal wastewater treatment within urban and rural areas.

\section{MATERIALS AND METHODS}

Location: The study was developed on the right bank of the sand trap of the Municipal Potable Water and Sewerage Company - EMAPA SA - Huancavelica located in the Santa Ana neighborhood of the Huancavelica district, province and region, with east coordinates $504066.40 \mathrm{~m} \mathrm{E}$ and north $8587053.49 \mathrm{~m} \mathrm{~S}$ located at an altitude of 3660 meters above sea level.

\section{Integrated biofilm and phytoremediation system}

For the design of each of the components, the hydraulic retention time (HRT) of the integrated system was taken into account, this value being 5-6 hours, the total time in which a biological system takes to degrade organic matter, to The 
present investigation was sized for 5.5 hours because it is a laboratory-scale system.

Pretreatment: A glass settler was built, this to retain colloidal particles that can obstruct the circulation of water through the $1 / 4$ inch hoses, likewise this system fulfilled the function of degreasing; the design had a dimension of $1 \times 0.3$ $\mathrm{m}$ and a depth of $0.45 \mathrm{~m}$, with a glass screen in the center that limited the passage of creams, this due to the density of oils and fats, under the principle of communicating glasses. This process had a flow rate of $0.011 / \mathrm{s}$ and contained a volume of water of $0.12 \mathrm{~m} 3$ and presented a TRH of 3 hours.

Biofilms: In this process, theoretical criteria were taken into account, where they mention that the contact time is between 10 - 20 seconds; For this, an inverted siphon was used, which started after the settler, a non-return valve of half an inch in diameter was placed at the entrance of the biological filter, this to prevent the return of water and generate a piston-type flow. For the support of the filtering material (calcareous tuff) of approximately $5 \mathrm{~cm}$ in diameter, a bucket of 18 liters was used occupying a volume of $0.02 \mathrm{~m} 3$ and for the distribution of the water a hose of $6 \mathrm{~mm}$ in diameter was used, which distributed a flow from $0.00731 / \mathrm{s}$

At the exit of the biological system, a secondary settler was placed, which is an additional component to a biological filter whose function is to collect the filtered water and then divert it to the next process.

Phytoremediation: The function of this process was to absorb nutrients and organic pollutants. In a double chamber aquarium, 4 plants were placed in each chamber, the capacity of each component was $0.03 \mathrm{~m} 3$, with a length of $0.70 \mathrm{~m}$, depth of $0.30 \mathrm{~m}$ and a hydraulic retention time of 2 hours with an outlet flow of $0.0041 / \mathrm{s}$, this to have greater contact with the plants.

\section{Field work}

The evaluation of the physical parameters (flow) and control parameters ( $\mathrm{pH}$ and temperature) was carried out, from July 15, 2019 to September 23, 2019, where a multiparameter Hach equipment was used to measure temperature and $\mathrm{pH}$. Samples were also taken for subsequent analysis in the laboratory.

Table 1

Monitoring frequency (monitoring of water samples)

\begin{tabular}{|c|c|c|c|}
\hline \multicolumn{4}{|l|}{ Monitoring frequency } \\
\hline \multirow{2}{*}{ Process description } & \multicolumn{3}{|c|}{2019} \\
\hline & July & August & September \\
\hline $\begin{array}{l}\text { Monitoring of } \\
\text { control parameters. }\end{array}$ & $\mathrm{X}$ & $\mathrm{X}$ & $\mathrm{X}$ \\
\hline $\begin{array}{l}\text { Determination of } \\
\text { BOD5. }\end{array}$ & & $\mathrm{X}$ & $\mathrm{X}$ \\
\hline $\begin{array}{l}\text { Analysis of samples } \\
\text { in the laboratory }\end{array}$ & & & $\mathrm{X}$ \\
\hline
\end{tabular}

\section{Laboratory work}

The determination of BOD5 (biochemical oxygen demand) was carried out in the central laboratory of the National University of Huancavelica from August 21, 2019 to September 23, 2019, where the information collected was processed to determine the efficiency of the integrated system, For this, the preparation of the solutions (nutrients A, $\mathrm{B}, \mathrm{C}$, and D) was carried out, according to detail:

Solution A: $0.25 \mathrm{~g}$ of Ferric Chloride Hexahydrate $(\mathrm{FeCl} 3$ - $6 \mathrm{H} 2 \mathrm{O}$ ) to one liter of distilled water. (It should not be exposed to light).

Solution B: $27.5 \mathrm{~g}$ of anhydrous Calcium Chloride $(\mathrm{CaCl} 2)$ to one liter of distilled water.

Solution C: $22.5 \mathrm{~g}$ of Magnesium Sulfate Heptahydrate $(\mathrm{MgSO} 4 \cdot 7 \mathrm{H} 2 \mathrm{O})$ to one liter of distilled water.

Solution D (Buffer): $8.5 \mathrm{~g}$ of monobasic Potassium Phosphate (KH2PO4) to one liter of distilled water.

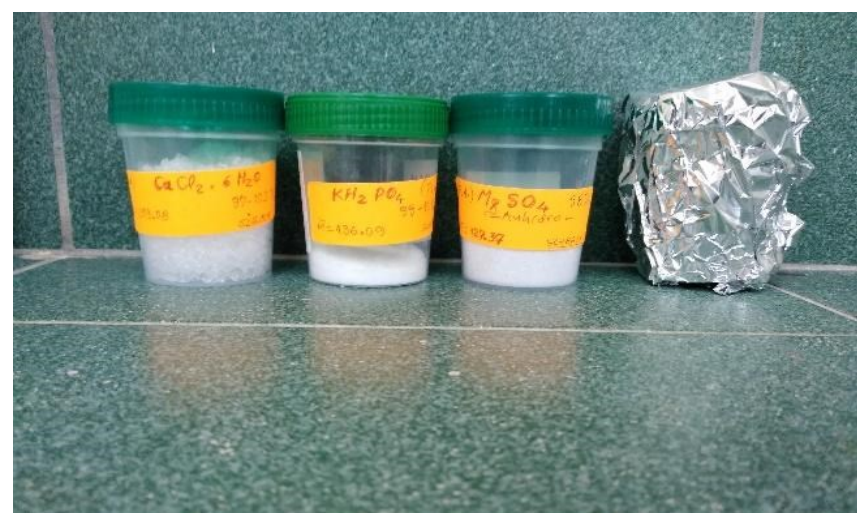

Figure 1. Compound substances.

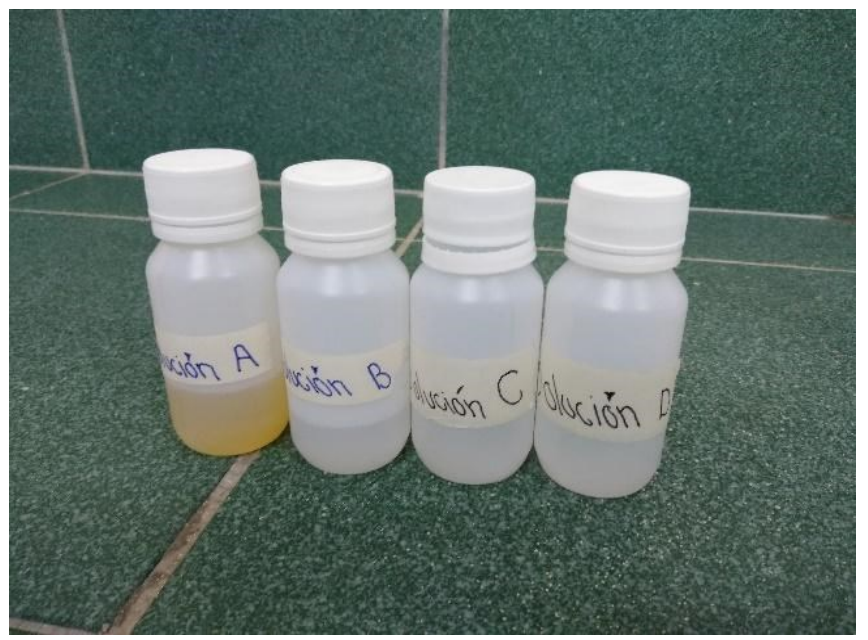

Figure 2. Solutions A, B, C and D.

$250 \mathrm{ml}$ of effluent and effluent sample were placed respectively in a beaker and subsequently $1 \mathrm{ml}$ of each solution was added with different and sterilized pipettes. To determine this parameter, the 6-position Velp Cientific BOD5 equipment was used, this equipment has 6 amber glass bottles and sensors, in which the samples were placed, the amber glass bottles were labeled, the stirring magnet was introduced. In each bottle, pellets were placed in the $\mathrm{CO} 2$ tanks up to the edge without overflowing through the holes in 
the walls, then the sensors, pressing the SET and START buttons at the same time, to choose the scale of $250 \mathrm{mg} \mathrm{O} 2$ / 1 , pressed the SET button and then START, starting the measurement.

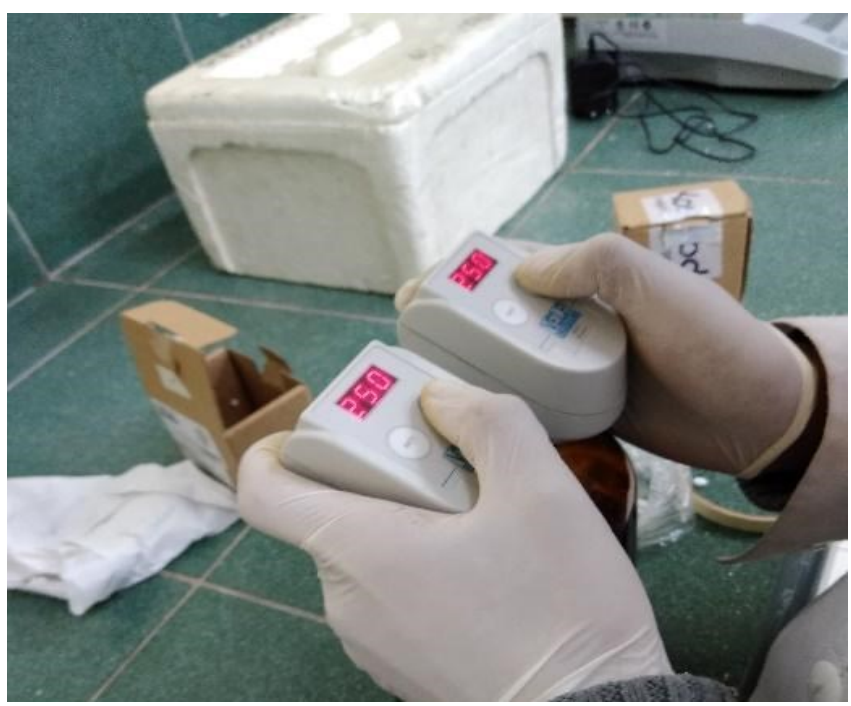

Figure 3. Choice of the $250 \mathrm{mg} \mathrm{O} 2$ / 1 scale.

Finally, the flasks were introduced into the stirring equipment that is located in the thermostatic refrigerator, taking into account the temperature of the thermostatic refrigerator at $20^{\circ} \mathrm{C}$. After 5 days elapsed, the measurement was carried out.

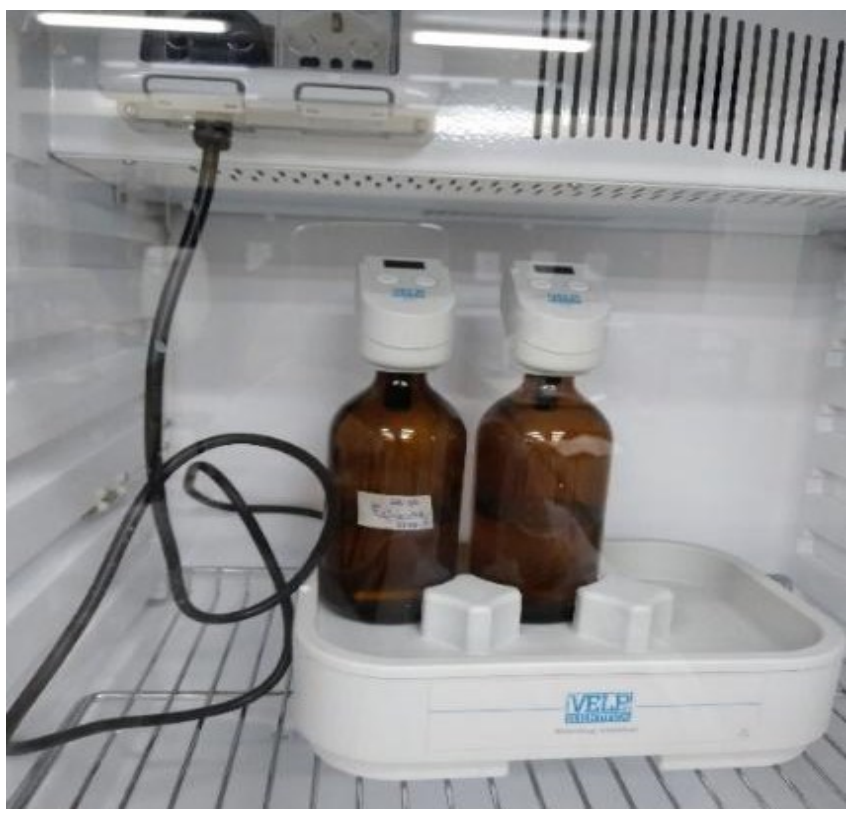

Figure 4. Connection of the shaking equipment to the incubator at $20^{\circ} \mathrm{C}$.

The parameters of COD, oils and fats, total suspended solids, total coliforms, fecal coliforms and Escherichiacoliforms were determined in the laboratory "LABECO Environmental Analysis SCRL" accredited by INACAL.

\section{Analysis of data}

Descriptive statistics and the T-Student test were used at $95 \%$ reliability by means of the criteria for determining the efficiency for the system. Before and after the wastewater treatment test, an analysis of the processed and ordered data was carried out, comparing them with the environmental legislation (Supreme Decree No. 003-2010-MINAM that approves the Maximum Permissible Limits for the effluents of Water Treatment Plants Domestic or Municipal Residuals - PML) thus evaluating whether the parameters comply with the aforementioned legal standard.

\section{RESULTS}

\section{Field phase}

Behavior of the temperature and $\mathrm{pH}$ of the water.

At the entrance of the integrated system there was an average temperature of $11.4^{\circ} \mathrm{C}$ and an exit of $12.07^{\circ} \mathrm{C}$, this small increase is due to the hydraulic retention time, since there is an increase in water temperature when going through each of the processes. Likewise, the $\mathrm{pH}$ was measured, usually this parameter must be kept within the range of 6.5 to 8.5 according to the LMP, this to guarantee an adequate functioning of the system, during the monitoring process at the entrance of the system there were average values $\mathrm{pH} 7.48$, and output 7.57, this indicates a correct operation of the system; It should be noted that having values above the established range indicates that the integrated system would not be working properly; In other words, as they are biological systems, they do not tolerate sudden changes in $\mathrm{pH}$.

Table 2

Average values of temperature and $\mathrm{pH}$.

\begin{tabular}{lcc}
\hline Parameters & Tributary & Effluent \\
\hline Temperature & 11.40 & 12.07 \\
$\mathrm{pH}$ & 7.48 & 7.58 \\
\hline
\end{tabular}

\section{Laboratory Phase}

Behavior of BOD5. The average values at the entrance and exit of the system, $154.42 \mathrm{ppm}$ and $84.67 \mathrm{ppm}$ respectively, obtaining a removal efficiency of $44.8 \%$, likewise within the 21 days in which the measurements were developed, maximum values were evidenced at the entrance of the system. integrated, of $198 \mathrm{ppm}$ and minimum values of 104 ppm, likewise at the output of the system maximum values of $104 \mathrm{ppm}$ and minimum values of $45 \mathrm{ppm}$, reaching the compliance with the LMP for the effluents of Municipal Domestic Wastewater Treatment Plants approved through DS003-2010-MINAM.

Table 3

Data analysis of BOD5 measurement

\begin{tabular}{lcc} 
& \multicolumn{2}{c}{ Half } \\
& Tributary & Effluent \\
\hline BOD5 & 154.43 & 84.67 \\
\hline
\end{tabular}




\section{Control de la DBO5}

250.00

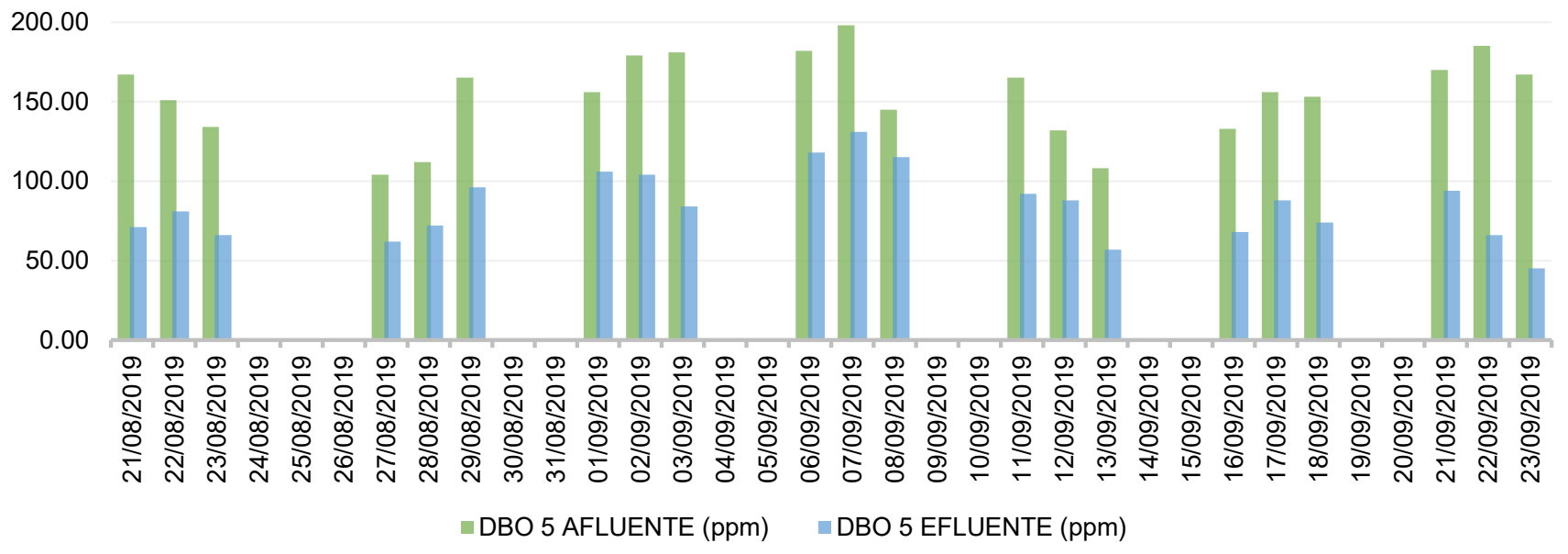

Figure 5. Measurement and control of BOD5

Behavior of COD, total coliforms, fecal coliforms, EscherichiaColi.

Upon entering the integrated system, $345 \mathrm{ppm}$ of COD (chemical oxygen demand) was observed, and at the end 115 ppm of COD was obtained, this value being very significant as shown in Figure 6; EF-1 represents the waste water at the inlet of the integrated system and EF-2 represents the waste water at the outlet of the integrated system, with values duly reduced; thus complying with the LMP for the effluents of Municipal Domestic Wastewater Treatment Plants approved by DS003-2010-MINAM, in the same way a removal efficiency of $67 \%$ is obtained; Likewise, microbiological parameters such as total coliforms, fecal coliforms, Escherichiacoli were analyzed, obtaining values as shown in Table 4 which are not within the allowed range.

Table 4

Results of water samples sent to the laboratory

\begin{tabular}{llllll}
\hline Laboratory Code & $\begin{array}{l}\text { 1434-1 } \\
\text { (Sample 1) }\end{array}$ & $\begin{array}{l}\text { 1434-2 } \\
\text { (sample 2) }\end{array}$ & Unit & LMP & Condition \\
\hline Client code & EF-01 & EF-02 & &
\end{tabular}

\section{Physico-chemical parameters}

\begin{tabular}{|c|c|c|c|c|c|}
\hline TSS & 179.0 & 171.3 & $\mathrm{mg} / \mathrm{L}$ & 150 & Fails \\
\hline Oils and fats & 537.8 & 505.7 & $\mathrm{mg} / \mathrm{L}$ & twenty & Fails \\
\hline COD & 3.4 .5 & 115 & $\mathrm{mg} / \mathrm{L}$ & 200 & Complies \\
\hline \multicolumn{6}{|c|}{ Microbiological Parameters } \\
\hline Total coliforms & $1.7 \times 107$ & $9.2 \times 105$ & $\mathrm{NMP} / 100 \mathrm{~mL}$ & $*$ & Fails \\
\hline $\begin{array}{l}\text { Thermotolerant } \\
\text { coliforms }\end{array}$ & $4.9 \times 106$ & $9.2 \times 105$ & $\mathrm{NMP} / 100 \mathrm{~mL}$ & 10,000 & Fails \\
\hline Escherichiacoli & $3.3 \times 106$ & $9.2 \times 105$ & $\mathrm{NMP} / 100 \mathrm{~mL}$ & $*$ & Fails \\
\hline
\end{tabular}


ISSNe: 2617-9156

\section{Discussion}

The system was designed according to the characterization study carried out by EMAPA SA - Huancavelica (laboratory ECOPROJET SAC, 2016) and by making a comparison with the results of the analyzed samples of the affluent in the present research work, it was determined that the parameters do not meet with current regulations at a significance level of 0.05 according to the Student's $t$ test.

\section{Analysis of (Student's t) for the biochemical oxygen demand (BOD5).}

\section{Table 5}

Student's t test for BOD5

\begin{tabular}{ll}
\hline Student's t for BOD5 removal efficiency \\
\hline Significance level (NS) & 0.05 \\
Confidence level (NC) & 0.95 \\
Hypothetical value (u) & 60 \\
Sample (n) & twenty-one \\
Degrees of freedom (n-1) & twenty \\
Mean (x) & 44.80 \\
Standard deviation (s) & 11.69 \\
Student's t test & $\mathbf{- 1 . 6 8}$ \\
\hline
\end{tabular}

According to the results obtained, the following is obtained:

$$
\text { Tcal }=\frac{X-u}{S / \sqrt{n}}
$$

Obtaining that the $\mathrm{T}$ cal or Student's $\mathrm{T}$ is $=-1.68$

With table $\mathrm{T}=-1.72$

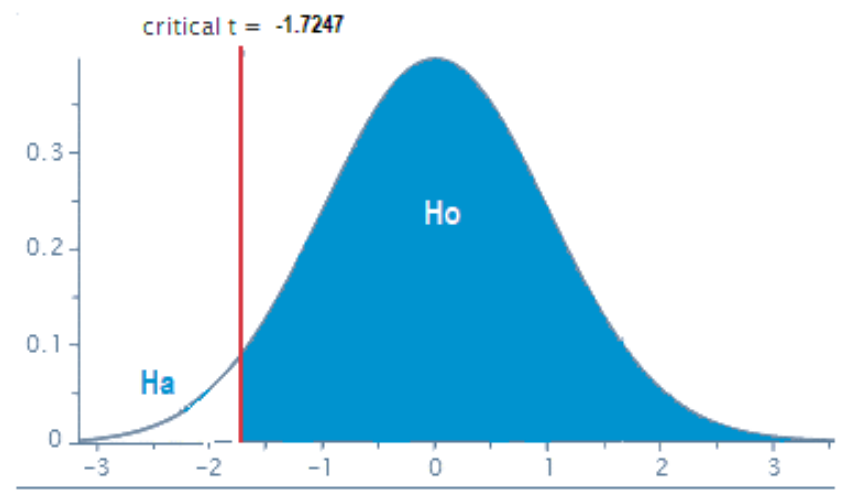

Figure 7.Critical values " $t$ " to accept or reject the null hypothesis Ho, in terms of BOD5.

The calculated T value was -1.68 less than $(<)$ the $\mathrm{T}$ values of the table - 1.7247 , for biochemical oxygen demand (BOD5) it is observed that there is a difference between the $\mathrm{T}$ values, with Student's $\mathrm{T}$ being the contrast test of hypothesis.

Attribution-NonCommercial 4.0 International (CC BY-NC 4.0)

\section{Statistical decision}

The null hypothesis (Ho) is accepted and the alternative hypothesis (Ha) is rejected Since the value of $\mathrm{T}$ calculated is $-1.68<$ than the value of $\mathrm{T}$ from table -1.72 , indicating that the value of the sample statistic ( $T$ calculated) is in the acceptance region for Ho, then the null hypothesis (Ho ) is accepted, and we conclude that: The removal efficiency of organic pollutants from municipal wastewater for the integrated biofilm and phytoremediation system with Nasturtium officinale (watercress) is less than $60 \%$.

According to the research by Espinoza (2017) where he evaluated the concentration of $10 \mathrm{ml} / 1$ of efficient microorganisms in a biofilter system, a minimum average decrease for BOD5 of $4 \%$ was found, and a maximum decrease of $16.24 \%$, also comparing His results with the research of Hernández (2010) where he used pumice stone and etch as filtering material and obtained removal efficiencies for BOD5 from $7.69 \%$, up to a maximum of $28.94 \%$, coal and gravel were also evaluated as filtering medium and the removal efficiency for BOD5 was 5.0\% up to a maximum of $39.76 \%$.

On the other hand, Rodríguez et al. (2010) made or the study of the comparison of lentils and water buchón in artificial wetlands in the treatment of wastewater and presents results of removal of organic matter (BOD5) between 70 and $86 \%$ when using the water buchón, and $58 \%$ when using lentils of water.

\section{Conclusions}

- According to the analysis of the characterization report carried out by EMAPA SA - Huancavelica (Laboratory ECOPROJET SAC, 2016), the wastewater has a high content of organic and inorganic matter, and total coliforms, so the values analyzed do not comply with the LMP for the effluents.

- The temperature variation is $1^{\circ} \mathrm{C}$, this small increase is due to the hydraulic retention time, on the other hand, the $\mathrm{pH}$ remained within the range established in the LMP.

- A BOD5 removal efficiency of $44.8 \%$ was obtained, also at the outlet of the system, the maximum and minimum values were $131 \mathrm{ppm}$ and $45 \mathrm{ppm}$ respectively, reaching the LMP for the effluents.

- The COD values comply with the LMP for the effluents, while the parameters of total coliforms, fecal coliforms and Escherichia coli, oils and fats and total suspended solids do not comply with the regulations, but it is evidenced that there was a removal capacity significant of the microbiological parameters.

\section{REFERENCES}

[1] Cervantes, A. (2009). Combined system for the treatment of wastewater for single-family homes. National Autonomous University of Mexico [Undergraduate Thesis].

[2] Charris, J., \& Caselles, A. (2016). Efficiency of 
ISSNe: 2617-9156

pollutant removal from domestic wastewater with experimental constructed wetlands planted with Cyperusligularis (Cyperaceae) and Echinochloacolonum (Poaceae). Water Technologies and Sciences, 7 (6), 93-103.

[3] Chernicharo, C. (2013). Principles of the Biological Treatment of Wastewater Anaerobic Reactors |. (University of Nariño, Ed.). Colombia.

[4] Delgadillo, O., Camacho, A., Perez, L., \& Andrade, M. (2010). Wastewater purification through artificial wetlands (Nelson Antequera). Cochabamba, Bolivia.

[5] Espinoza, A. (2017). Reduction of the BOD, COD and STD of the domestic wastewater of Santiago de Chuco using a pumice stone biofilter. César Vallejo University [Undergraduate Thesis].

[6] Hammond, D. (2010). Thescience of synthesis: exploring the social implications of general systemstheory. University Press of Colorado.

[7] Hernández, J. (2010). Alternatives for the treatment of gray wastewater of domestic origin. University of San Carlos of Guatemala.

[8] ECOPROJET SAC Laboratory (2016). Test report: 35225/2016. Huancavelica.

[9] Monzón, JIT, García, ALE, Florio, L. de, Montero, RD, Cortazar, ALG de, \& Hernández, MLR (2012). Innovative biofilm technologies for wastewater treatment: twenty-five years of research by the Environmental Engineering Group of the University of Cantabria. Civil Engineering, 168, 61-74.

[10] Núñez, RA, Meas, Y., Ortega, R., \& Olguín, E. (2004). Phytoremediation: fundamentals and applications, 15.

[11] Quispe, A. (2018). Efficiency evaluation between two biofilter systems for the treatment of domestic wastewater in the town of Carapongo, Lurigancho Chosica. Federico Villarreal National University [Undergraduate Thesis].

[12] Rodríguez, JP, Gómez, E., Garavito, L., \& López, F. (2010). Comparison study of domestic wastewater treatment using lentils and water buchon in artificial wetlands. Water Technology and Sciences, (1), 59-68.

[13] Rodríguez Miranda, Juan P., García-Ubaque, César A., \& García-Ubaque, Juan C .. (2016). Diseases transmitted by water and basic sanitation in Colombia. Journal of Public Health, 18 (5), 738-745. https://dx.doi.org/10.15446/rsap.v18n5.54869

[14] Sanhueza, C., Palma, J., Valenzuela, P., Araneda, O., \& Calderón, K. (2011). Evaluation of the geotechnical behavior of Chilean volcanic soils for use as filter material in the treatment of domestic wastewater. Revista de La Construcción, 10 (2), 6681.https://doi.org/10.4067/S0718915X2011000200007n. [Undergraduate thesis].

[15] Siguí, L. (2013). Design and construction of an intermittent gravel filter without recirculation and comparison with theoretical efficiencies of filters with recirculation for the treatment of domestic wastewater. University of San Carlos de Guatemala [Undergraduate Thesis].

[16] Ugaz, F. (2018). Reuse of wastewater, biologically treated for the irrigation of the botanical garden, Trujillo, La Libertad - Peru. National University of Trujillo [Undergraduate Thesis].

[17] Vasquez, S. (2017). Efficiency analysis of a Biofilter prototype in the treatment of wastewater for irrigation in Trapiche, Comas, 2017. Universidad César Vallejo [Undergraduate Thesis]

[18] Vicente, J. (2016). Determination of the efficiency of sawdust and coconut fiber used as packaging for the removal of pollutants in Biofilters for wastewater treatment. UTE Approach, 7 (3) 41.https://doi.org/10.29019/enocusute.v7n3.104[Under graduate thesis] 